\title{
Understanding the Mechanism of Arsenic Mobilisation and Behaviour in Tailings Dams*
}

\author{
${ }^{1}$ B. Koomson, ${ }^{2}$ E. K. Asiam, ${ }^{3}$ W. Skinner and ${ }^{3}$ J. Addai-Mensah \\ ${ }^{1}$ Kwame Nkrumah University of Science and Technology, Kumasi, Ghana \\ ${ }^{2}$ University of Mines and Technology, Tarkwa, Ghana \\ ${ }^{3}$ University of South Australia, Mawson Lakes Campus, Mawson Lakes SA 5095, Australia
}

Koomson B., Asiam, E. K, Skinner, W., and Addai-Mensah, J., (2017), "Understanding the Mechanism of Arsenic Mobilisation and Behaviour in Tailings Dams", Ghana Mining Journal, Vol. 17, No. 1, pp. 85 - 89.

\begin{abstract}
This study was carried out on leaching of tailings at $30{ }^{\circ} \mathrm{C}$ and $40{ }^{\circ} \mathrm{C}$. The mineralogical and chemical composition of the tailings material were determined by Quantitative X-Ray Diffractometry (QXRD) and Scanning Electron Microscopy combined with Energy Dispersive Spectroscopy (SEM-EDAX). The study revealed that the tailings contain sulphides (arsenopyrite and pyrite) which can leach to produce arsenic (As) and other ions in solution. The acid released during leaching depends on the temperature of leaching. More acid was produced at higher temperature $\left(40{ }^{\circ} \mathrm{C}\right)$ than lower temperature $\left(30^{\circ} \mathrm{C}\right)$. It was established that arsenic precipitation from solution was higher at higher temperature $\left(40{ }^{\circ} \mathrm{C}\right)$ than lower temperature $\left(30^{\circ} \mathrm{C}\right)$. Mimicking the study in a typical tailings environment, it could be proposed that As mobilisation will be enhanced at lower temperature $\left(30^{\circ} \mathrm{C}\right)$ than at higher temperature $\left(40{ }^{\circ} \mathrm{C}\right)$.
\end{abstract}

Keywords: Tailings, Leaching, Arsenopyrite, Heavy metals and Temperature

\section{Introduction}

Alkaline cyanide leaching of gold from refractory ores usually requires finely ground ores $(80 \%$ passing $106 \mu \mathrm{m}$ ) for efficient metal recovery. This produces very fine tailings with a relatively high specific surface area whereby unstable compounds in the tailings material can undergo decomposition. Some of these unstable materials are pyrite, arsenopyrite and other sulphides which can be easily oxidized once exposed to air and water (Warhurst and Noronha, 2000; Fan et al., 2016). The oxidation of these sulphides will produce metal laden acid which can be mobilised into the geoenvironment (Wang and Mulligan, 2009; Heikkinen and Raisanen, 2009; Carvalho et al., 2014).

The release of As and other heavy metals from tailings into the geo-environment can adversely affect the biota (Bain et al., 2000; Armienta et al., 2001; Jung, 2001; Romero et al., 2010) which manifests in the following: keratosis, neuropathy, liver fibrosis, anemia, burning sensation of eyes, chronic lung disease, gangrene of toes/black foot disease, body weakness, skin cancer and solid swelling of legs, osteoporosis, decreased birth weight, kidney disease, cancer, and skeletal damage in humans, and in plants, stunted growth via inhibition of phosphate enzyme activities and protein synthesis (Ter Welle and Slater, 1967; Sckerl and Frans, 1969; Clijsters and Van Assche, 1985; Lu, 1990; Burlo et al., 1999; Guha, 2003; Stoeva et al., 2005; Choong et al., 2007).
Therefore, effluent from tailings is normally treated before it is discharged into the geo-environment using the following methods: chemical precipitation, ion-exchange, adsorption, membrane filtration and coagulation/flocculation (Dabrowski et al., 2004; Fu and Wang, 2011; Hua et al., 2012; Koomson and Asiam, 2013).

The efficiency of these methods will largely depend on the nature of the effluent. Therefore, it is necessary to understand the geo-chemical process occurring in the tailings mass. The present study seeks to understand the influence of temperature on the leaching of tailings material.

\section{Resources and Methods Used}

\subsection{Tailings Characterisation}

The tailings material used in this study was obtained from a gold mine in Ghana. The mineralogical composition of the tailings material was determined using: quantitative $\mathrm{X}$-ray diffractometry (QXRD; Phillips PW 1050 X-ray generator equipped with Sietronic automated data collection). Scanning electron microscopy (SEM; FEI Quanta 450 FEG) combined with energy dispersive spectroscopy (EDAX; Apollo X SDD) was used to determine the morphology and spot composition of the sulphide minerals. Chemical composition was determined by inductively coupled plasma optical emission spectrometry (ICP-OES; Perkin Elmer 5300 DV) after acid digestion of sample. Particle size distribution was determined by laser diffraction using Mastersizer 
2000 (Malvern Instruments Ltd., U.K.). Specific surface area of the tailings was determined by the Brunauer, Emmett and Teller (BET) method (Brunauer et al., 1938) using Gemini VII 2390 (Micrometrics, USA).

\subsection{Leaching}

Various slurries (each containing $40 \mathrm{wt} \%$ solids) conditioned to $\mathrm{pH} 2$ were isothermally leached on a rotating orbital mixer incubator rack (Ratek) at 260 $\mathrm{rpm}$ at $30^{\circ} \mathrm{C}$ for 7 days. Samples were removed at $24 \mathrm{~h}$ interval and the $\mathrm{pH}$ was measured. The slurry was then centrifuged at $4500 \mathrm{rpm}$ for $30 \mathrm{~min}$ using the Heraeus multifuge 3S-R centrifuge. The supernatant solutions were then carefully collected, and filtered through a $0.25 \mu \mathrm{m}$ Teflon membrane. The filtrate was then analysed for As and Fe using an ICP-OES. The experiment was repeated at 40 ${ }^{\circ} \mathrm{C}$.

\section{Results and Discussion}

\subsection{Mineralogical Analysis}

The results of QXRD is presented in Table 1. It can be inferred that the tailings material consists mainly of quartz and muscovite. The minor materials are chlorite and siderite. The results of the chemical composition of the tailings is presented in Table 2 . The major elements are Fe, S, Ca and As. Although no sulphide was identified in the QXRD analysis, SEM-EDAX analysis (Fig.1) indicated that arsenopyrite and pyrite were present in the tailings material. It can therefore be inferred that these sulphide materials can oxidise. Hence, the presence of trace amounts of hematite could be due to the weathering product of the sulphides.

Table 1 Mineralogical Composition of Tailings

\begin{tabular}{||l|c|}
\hline $\begin{array}{c}\text { Mineralogical composition } \\
\text { minerals in tailings }\end{array}$ & of major \\
\hline \hline Mineral & 48 \\
\hline \hline Quartz & 41 \\
\hline Muscovite & 5 \\
\hline Chlorite & 4 \\
\hline Siderite & $<1$ \\
\hline Hematite & $<1$ \\
\hline Amorphous Content & $\sim 100$ \\
\hline Total & \\
\hline
\end{tabular}

Table 2 Chemical Composition of Tailings

\begin{tabular}{||l|c||}
\hline \hline Element & $\begin{array}{c}\text { Concentration } \\
\left(\mathbf{m g ~ k g}^{-1}\right)\end{array}$ \\
\hline \hline $\mathrm{As}$ & 490 \\
\hline $\mathrm{Cu}$ & 64 \\
\hline $\mathrm{Fe}$ & 60000 \\
\hline $\mathrm{S}$ & 2650 \\
\hline $\mathrm{Ca}$ & 2300 \\
\hline \hline
\end{tabular}

\subsection{Leaching}

The results of particle size analysis of the tailings material is presented in Fig 2. It can be inferred that the $d_{50}$ is $29.10 \mu \mathrm{m}$. The tailings' specific surface area was found to be $3.58 \mathrm{~m}^{2} / \mathrm{g}$ indicating a relatively high surface area. Hence, these parameters can enhance the leachability of tailings.
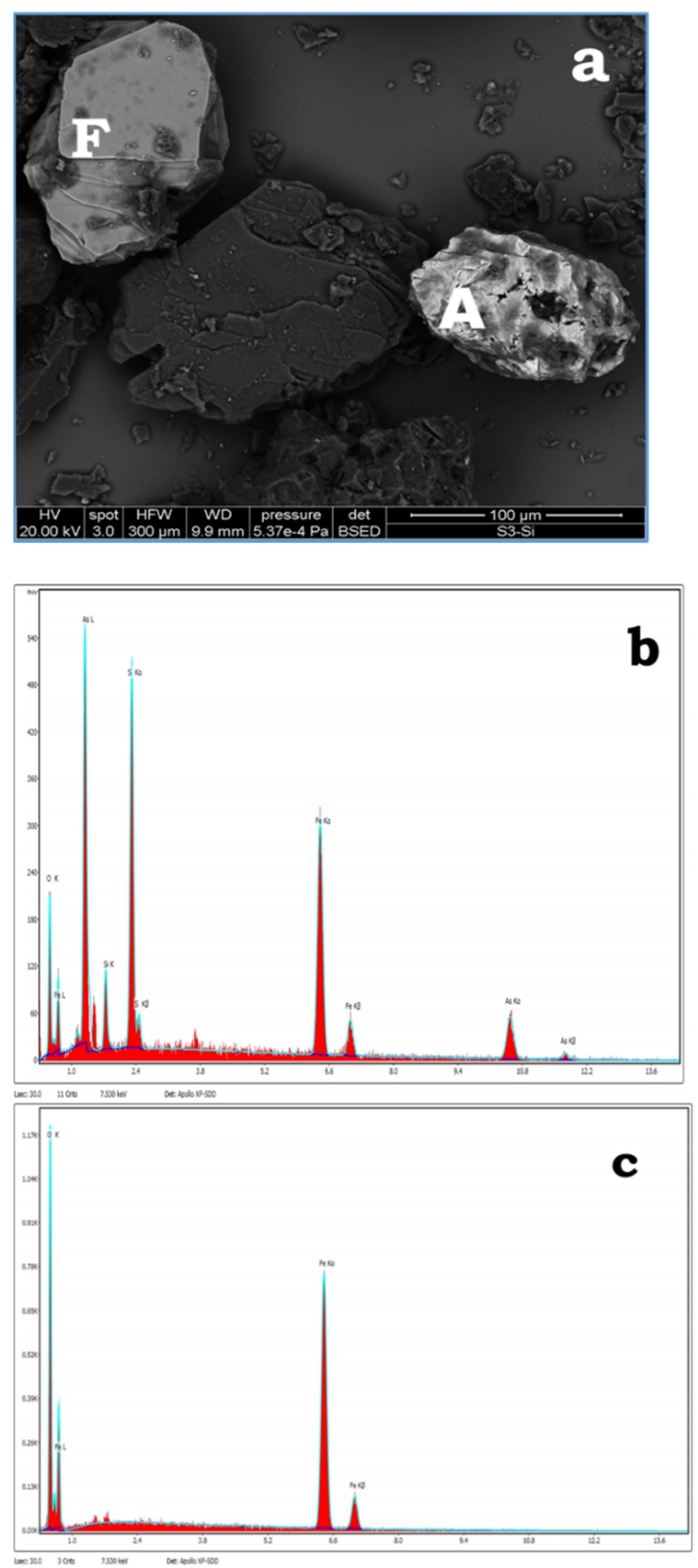

Fig. 1 SEM Backscattered Electron Micrograph (tailings) showing a) Arsenopyrite (A) and Iron Oxide (F) Grains surrounded by Gangue Material; b) EDAX Spectra indicating $\mathrm{Fe}-\mathrm{As}-\mathrm{S}$ Composition of the Arsenopyrite (A) Grain; and c) EDAX Spectra showing Fe-O 


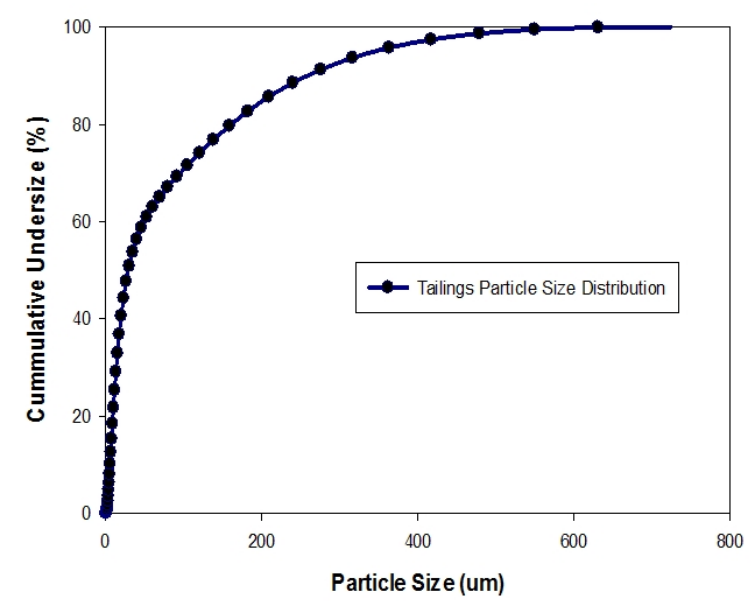

Fig. 2 Tailings Particle Size Distribution Curve

results of leaching at temperatures 30 and $40{ }^{\circ} \mathrm{C}$ are presented in Fig. 3 and Fig. 4 respectively. It can be seen that at $40{ }^{\circ} \mathrm{C}$ the As dissolution is found to increase to $3.36 \mathrm{mg} / \mathrm{l}$ within $24 \mathrm{~h}$ and thereafter, it decreased rapidly to $0.06 \mathrm{mg} / \mathrm{l}$ after $168 \mathrm{~h}$. The $\mathrm{pH}$ trend at $40{ }^{\circ} \mathrm{C}$ increased from 2 to 5.2 within $168 \mathrm{~h}$ (Fig. 5). The $\mathrm{Fe}$ dissolution at $40{ }^{\circ} \mathrm{C}$ is found to increase to $382.70 \mathrm{mg} / \mathrm{l}$ after $24 \mathrm{~h}$ and shows a sinusoidal trend decreasing gradually to $15.76 \mathrm{mg} / \mathrm{l}$ after $168 \mathrm{~h}$. At $30{ }^{\circ} \mathrm{C}$, on the other hand, As dissolution was observed to increase gradually from $0.03 \mathrm{mg} / \mathrm{l}$ at $24 \mathrm{~h}$ to $0.2 \mathrm{mg} / \mathrm{l}$ at $168 \mathrm{~h}$. Fe dissolution increased rapidly to $55.30 \mathrm{mg} / \mathrm{l}$ after 24 $\mathrm{h}$ and decreased gradually to $0.31 \mathrm{mg} / \mathrm{l}$ after $168 \mathrm{~h}$ showing a similar trend to that at $40^{\circ} \mathrm{C}$.

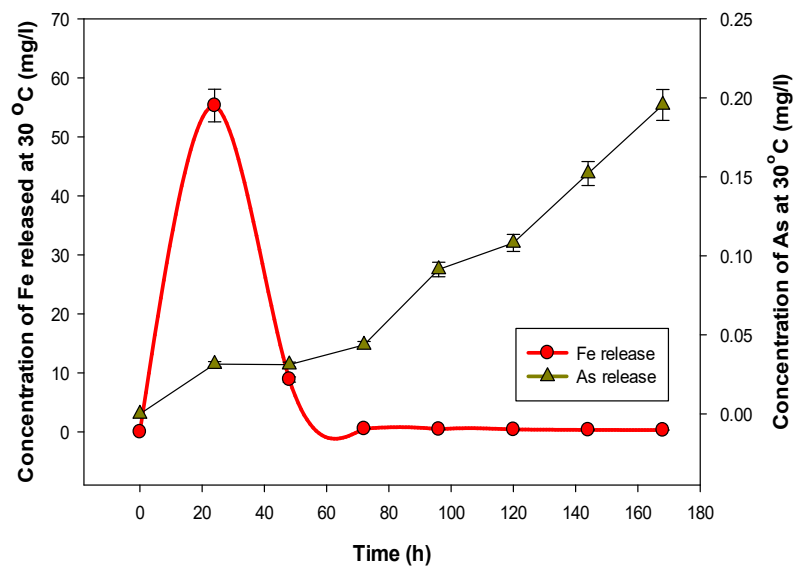

Fig. 3 Fe and As Release Concentrations measured as a Function of Time at $30^{\circ} \mathrm{C}$

The experimental observation revealed that a brownish precipitate was seen in the case of leaching at $40 \quad{ }^{\circ} \mathrm{C}$ while a greenish-yellow colouration was found at $30{ }^{\circ} \mathrm{C}$. Furthermore, the change in $\mathrm{pH}$ trend at $30{ }^{\circ} \mathrm{C}$ is higher than $40{ }^{\circ} \mathrm{C}$ indicating the leaching at $40{ }^{\circ} \mathrm{C}$ produces more acidic solution. This can be explained as follows: the $\mathrm{Fe}$ species at $40{ }^{\circ} \mathrm{C}$ shows the presence of $\mathrm{Fe}^{3+}$ as inferred by a brownish precipitate during experimental investigations. However, at $30^{\circ} \mathrm{C}$, the precipitate formed showed a greenish-yellow colouration. From this, the mechanism of hydration of Fe species may be described as follows:

$$
\begin{array}{rc}
\text { At } 30{ }^{\circ} \mathrm{C} ; & \mathrm{Fe}^{2+}+2 \mathrm{H}_{2} \mathrm{O} \\
& \rightarrow \mathrm{Fe}(\mathrm{OH})_{2} \\
& +2 \mathrm{H}^{+} \\
\text {At } 40{ }^{\circ} \mathrm{C} \quad & \mathrm{Fe}^{3+}+\mathrm{H}_{2} \mathrm{O} \\
& \rightarrow \mathrm{Fe}(\mathrm{OH})_{3} \\
& +3 \mathrm{H}^{+}
\end{array}
$$

From Equation 1, it is observed that the overall/net acid produced by $\mathrm{Fe}^{2+}$ hydration is lower than that of $\mathrm{Fe}^{3+}$ (equation 2) and this explained the observed trend in Fig. 5.

The dissolution of $\mathrm{Fe}$ is higher at $40{ }^{\circ} \mathrm{C}$ than $30{ }^{\circ} \mathrm{C}$. For example at $30{ }^{\circ} \mathrm{C}$, Fe dissolves rapidly and reaches a peak $(55 \mathrm{mg} / \mathrm{l})$ at $24 \mathrm{~h}$ and thereafter decreased rapidly to about $9 \mathrm{mg} / \mathrm{l}$ at $48 \mathrm{~h}$. In contrast, at $40{ }^{\circ} \mathrm{C}, \mathrm{Fe}$ increased rapidly in solution to $383 \mathrm{mg} / \mathrm{l}$ and was sustained until $100 \mathrm{~h}$ and thereafter it decreased gradually to about $15 \mathrm{mg} / \mathrm{l}$ at $168 \mathrm{~h}$. The mechanism of $\mathrm{Fe}$ precipitation in solution can be given as follows:

$$
\begin{aligned}
\mathrm{Fe}^{2+}+1 / 4 \mathrm{O}_{2}+ & 5 / 2 \mathrm{H}_{2} \mathrm{O} \\
& \rightarrow \mathrm{Fe}(\mathrm{OH})_{3} \\
& +2 \mathrm{H}^{+}
\end{aligned}
$$

Thus, the presence of oxygen will enhance the precipitation reaction since the solubility of gases decreases with increasing temperature (Gerrard, 1976). The amount of oxygen in solution at $30^{\circ} \mathrm{C}$ will be more than $40{ }^{\circ} \mathrm{C}$. Consequently, the precipitation of $\mathrm{Fe}$ at $30{ }^{\circ} \mathrm{C}$ will be higher than 40 ${ }^{\circ} \mathrm{C}$ resulting in a delayed precipitation of $\mathrm{Fe}$ as observed at $40{ }^{\circ} \mathrm{C}$.

Furthermore, the behaviour of As can be explained as follows: at $40{ }^{\circ} \mathrm{C}$, there is more $\mathrm{Fe}^{3+}$ in solution. As a result, As is removed rapidly from solution as ferric arsenate whereas at $30^{\circ} \mathrm{C}$ most of the $\mathrm{Fe}$ had precipitated after $50 \mathrm{~h}$ during which period As had not sufficiently dissolved. Hence there were insufficient $\mathrm{Fe}^{3+}$ in solution to precipitate the dissolving As, therefore, its concentration was high.

This study has shown that leaching temperature has marked influence on $\mathrm{Fe}$ and As species in solution. Mimicking the leaching reactions in a typical tailings environment, it could be proposed that As mobilization will be enhanced at lower temperature than at higher temperature. 


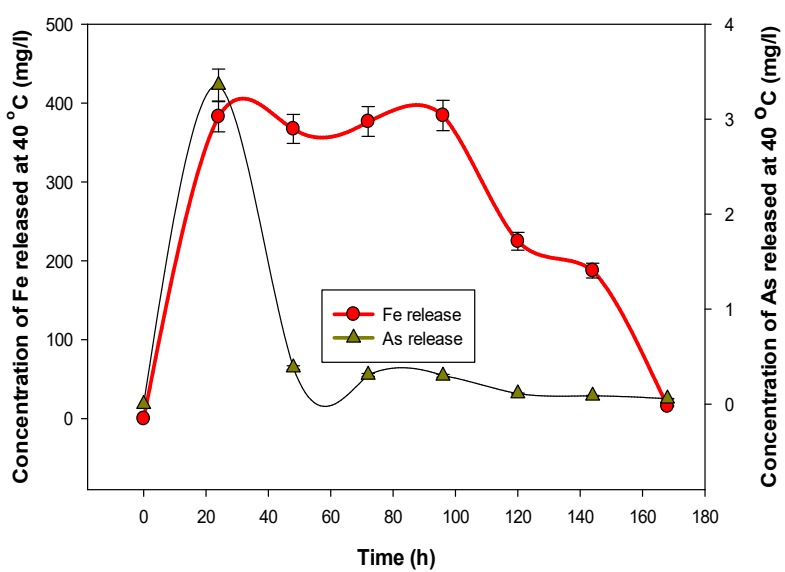

Fig. 4 Fe and As Release Concentrations measured as a Function of Time at $40{ }^{\circ} \mathrm{C}$

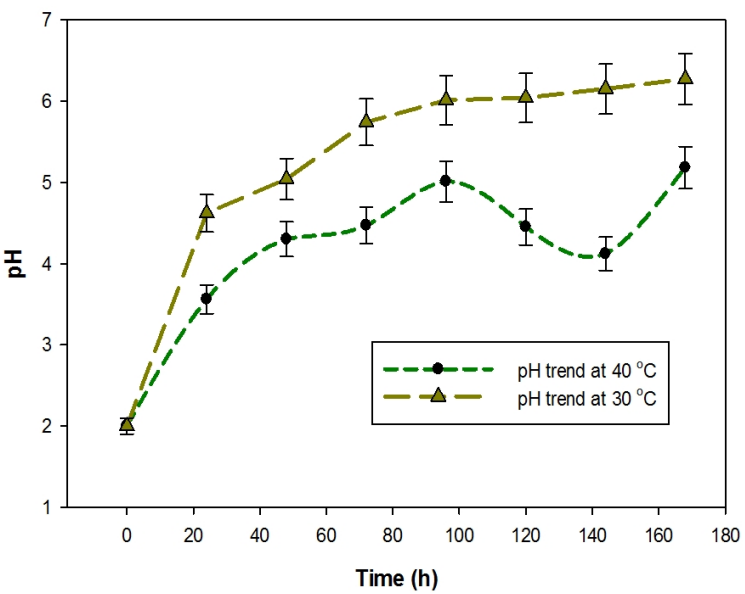

Fig. 5 Leaching of $\mathrm{Fe}$ and $\mathrm{As} \mathrm{pH}$ Trends as Function of Time at 30 and $40{ }^{\circ} \mathrm{C}$

\section{Conclusions}

This study revealed that sulphide bearing tailings can leach and produce As and Fe in solution.

The acid released during leaching depends on the temperature of leaching. More acid is released at a higher temperature than at lower temperature.

It was found that As precipitation will be higher at higher temperature than lower temperature.

Mimicking reactions in a typical tailings environment, it could be proposed that As mobilization will be enhanced at lower temperature $\left(30^{\circ} \mathrm{C}\right)$ than a higher temperature $\left(40^{\circ} \mathrm{C}\right)$.

\section{Acknowledgements}

Financial support from the Robert S. McNamara Fellowship, World Bank towards this work is highly appreciated. The authors also wish to thank the Future Industries Institute (FII), University of South Australia (UniSA), Australia for their immense support.

\section{References}

Armienta, M.A., Villasenor, G., Rodriguez, R., Ongley, L. K. and Mango, H., (2001), "The role of arsenic-bearing rocks in groundwater pollution at Zimapan Valley, Mexico", Environmental. Geology, Vol. 40 (4), pp. 571581.

Bain, J. G., Blowes, D. W., Robertson, W. D. and Frind, E. O., (2000), "Modeling of Sulphide oxidation with reactive transport at a mine drainage site", Journal of Contaminant, Hydrology, Vol. 41 (1), pp. 23-47.

Brunauer, S., Emmett, P.H. and Teller, E., (1938), "Adsorption of gases in multimolecular layers", Journal of the American chemical society, Vol. 60 (2), pp. 309-319.

Burlo, F., Guijarro, I., Carbonell-Barrachina, A.A., Valero, D. and Martinez-Sanchez, F., (1999), Arsenic species: effects on and accumulation by tomato plants. Journal of Agricultural and Food Chemistry, 47 (3), pp. 1247-1253.

Carvalho, P.C.S., Neiva, A.M.R., Silva, M.M.V.G. and Antunes, I.M.H.R., (2014), Metal and metalloid leaching from tailings into streamwater and sediments in the old $\mathrm{Ag}-\mathrm{Pb}-\mathrm{Zn}$ Terramonte mine, northern Portugal. Environmental earth sciences, Vol. 71 (5), pp. 2029-2041.

Choong, T.S., Chuah, T.G., Robiah, Y., Koay, F.G. and Azni, I., (2007), "Arsenic toxicity, health hazards and removal techniques from water: an overview", Desalination, Vol. 217 (1), pp. 139166.

Clijsters, H. and Van Assche, F., (1985), "Inhibition of photosynthesis by heavy metals", Photosynthesis Research, Vol. 7 (1), pp. 31-40.

Dabrowski, A., Hubicki, Z., Podkościelny, P. and Robens, E., (2004), "Selective removal of the heavy metal ions from waters and industrial wastewaters by ion-exchange method", Chemosphere, Vol. 56 (2), pp. 91-106.

Fan, L., Zhou, X., Luo, H., Deng, J., Dai, L., Ju, Z., Zhu, Z., Zou, L., Ji, L., Li, B. and Cheng, L., (2016), "Release of Heavy Metals from the Pyrite Tailings of Huangjiagou Pyrite Mine: Batch Experiments", Sustainability, Vol. 8 (1), pp. 96.

Fu, F. and Wang, Q., (2011), "Removal of heavy metal ions from wastewaters: a review" Journal of Environmental Management, Vol. 92 (3), pp. 407-418.

Gerrard, W., (1976), The Solubility of Gases in Liquids, Plenum Press, New York, 273 pp.

Guha Mazumder, D.N., (2003), "Chronic arsenic toxicity: clinical features, epidemiology, and treatment: experience in West Bengal", Journal of Environmental Science and Health, Part A, Vol. 38 (1), pp. 141-163.

Heikkinen, P.M., Räisänen, M.L. and Johnson, R.H., (2009), "Geochemical characterisation of 
seepage and drainage water quality from two sulphide mine tailings impoundments: acid mine drainage versus neutral mine drainage", Mine Water and the Environment, Vol. 28, No. 1, pp. 30-49.

Hua, M., Zhang, S., Pan, B., Zhang, W., Lv, L. and Zhang, Q., (2012), "Heavy metal removal from water/wastewater by nanosized metal oxides: a review", .Journal of Hazardous Materials, Vol. 211, pp. 317-331.

Jung, M. C., (2001), "Heavy metal contamination of soils and waters in and around the Imcheon Au-Ag mine", Korea. Appl. Geochem., Vol. 16, pp. 1369-1375.

Koomson, B. and Asiam, E.K., (2013), "Studies on Arsenic Release and its Mitigation from Tailings Dam Using Nanomagnetite Particles", Ghana Mining Journal, Vol. 14, pp. 66-69.

Lu, F.J., (1990), "Fluorescent humic substances and blackfoot disease in Taiwan", Applied Organometallic Chemistry, Vol. 4 (3), pp. 91195.

Romero, F.M., Prol-Ledesma, R.M., Canet, C., Alvares, L.N. and Pérez-Vázquez, R., (2010), "Acid drainage at the inactive Santa Lucia mine, western Cuba: natural attenuation of arsenic, barium and lead, and geochemical behavior of rare earth elements", Applied Geochemistry, Vol. 25 (5), pp. 716-727.

Sckerl, M.M. and Frans, R.E., (1969), Translocation and Metabolism of MAA- ${ }^{1}$ C in Johnsongrass and Cotton. Weed Science, Vol 17 (4), pp. 421-427.

Stoeva, N., Berova, M. and Zlatev, Z., (2005), "Effect of arsenic on some physiological parameters in bean plants", Biologia Plantarum, Vol. 49 (2), pp. 293-296.

Ter Welle, H.F. and Slater, E.C., (1967),

"Uncoupling of respiratory-chain phosphorylation by arsenate", Biochimica et Biophysica Acta (BBA)-Bioenergetics, Vol. 143 (1), pp.1-17.

Wang, S. and Mulligan, C.N., (2009), "Enhanced mobilization of arsenic and heavy metals from mine tailings by humic acid", Chemosphere, Vol. 74 (2), pp. 274-279.

Warhurst, A. and Noronha, L., (2000), Environmental Policy in Mining: Corporate Strategy and Planning for Closure, Lewis Publishers, Washington DC, pp. 118 - 139.

\section{Authors}

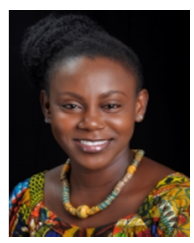

Bennetta Koomson holds an MPhil and a BSc degree in Minerals Engineering from University of Mines and Technology (UMaT), Tarkwa, and the Kwame Nkrumah University of Science and Technology (KNUST), Kumasi, respectively. She is currently a lecturer at KNUST and in her second year of $\mathrm{PhD}$ study at UMaT. This study forms part of her research project entitled "Nanolithosorption of arsenic from mine waters". Her research interests are; nanotechnology, waste management, water quality monitoring and waste water treatment.

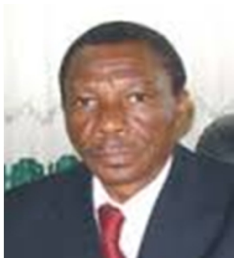

E. K. Asiam holds a BSc and $\mathrm{PhD}$ Degrees in Chemistry and Metallurgy respectively. $\mathrm{He}$ is an Associate Professor of Minerals Engineering at the University of Mines and Technology, Tarkwa, Ghana. His research interests are; mine waste management, precious mineral beneficiation and aqueous processes in minerals engineering. In particular, processing of refractory gold ores and environmental quality assessment and management.

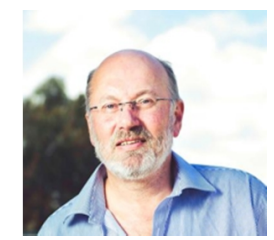

William Skinner holds a $\mathrm{PhD}$ and BSc. Degrees in Applied Physics and Physics respectively. He is a Research Professor and Strand Leader - Minerals \& Resources Engineering at the Future Industries Institute, University of South Australia, Australia. His research interests are; minerals processing, geochemistry and mineral surface science. In particular, mineral and material surface chemistry together with forensics, environmental science and biomaterials.

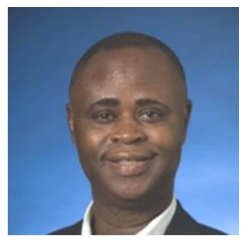

Jonas Addai-Mensah holds a PhD, MSc. and BSc. Degrees in Chemical Engineering. He is an Adjunct Professor at the Future Industries Institute, University of South Australia, Australia. He applies his skills and expertise in the field of resource engineering/extractive metallurgy (minerals processing and waste treatment) and chemical and interfacial engineering as an approach to enhanced and innovative materials processing. 